\title{
AZ MSSC SZURKOLÓI MOTIVÁCIÓS SKÁLA ADAPTÁLÁSA EGYETEMI HALLGATÓK KÖRÉBEN
}

ADAPTATION OF MSSC FAN MOTIVATION SCALE IN UNIVERSITY STUDENTS

\author{
Balogh Renátó1, Bácsné Bába Éva² \\ ${ }^{1} \mathrm{PhD}$ hallgató, ${ }^{2}$ egyetemi docens \\ ${ }^{1}$ Debreceni Egyetem, Gazdaságtudományi Kar, Ihrig Károly Gazdálkodás- és \\ Szervezéstudományok Doktori Iskola, ${ }^{2}$ Debreceni Egyetem, Gazdaságtudományi Kar \\ E-mail: balogh.renato@econ.unideb.hu, bacsne.baba.eva@econ.unideb.hu
}

\section{Összefoglalás}

A látvány-csapatsportok esetében az üzleti bevételek közül, különös jelentőséggel bír a fogyasztói piacról származó, hiszen nagymértékben befolyásolja a további piacok működését. Kijelenthető, hogy fogyasztók nélkül nem beszélhetünk látványsportról. Cikkünkben arra a kérdésre kerestük a választ, hogy az egyes magyar látvány-csapatsportágak mérkőzései iránti érdeklődést milyen tényezők befolyásolják. A kérdés megválaszolása érdekében adaptáltuk az MSSC szurkolói motivációs skálát. A kérdőív fordítása után kutatásunkat a Debreceni Egyetem Gazdaságtudományi, illetve a Gyermeknevelési és Gyógypedagógiai Kar hallgató körében végeztük $(\mathrm{n}=178)$. A megbízhatósági vizsgálat után faktorelemzést végeztünk, amely meghatározta a mérkőzések iránti érdeklődést befolyásoló tényezőket (látványosság, csapattal való azonosulás, szórakozás, vonzalom, közösséghez való tartozás). Az eredmények segítséget nyújthatnak a szurkolók magatartásának megismerését, amely hozzájárulhat az átlagnézőszámok emelkedéséhez.

\begin{abstract}
In is case of spectacular team sports the business revenues are of particular relevance to the consumer market as they greatly influence the functioning of further markets. It can be stated that without consumer we can not talk about spectacular sport. In our article, We were looking for the answer to which factors influencing interest in games of the Hungarian spectacular sports. In order to answer this question, We adapted the MSSC fan motivation scale. After translating the survey, my research was carried out at the University of Debrecen, Faculty of Economics and Business and Faculty of Education for Children and Special Educational Needs $(n=178)$. After the reliability test, We made a factor analysis that determined the factors affecting interest in the matches (aesthetic, team identification, entertainment, attraction, community affiliation). The results can help you get to know the behavior of fans, which can help increase the average attendance of the events.
\end{abstract}

Kulcsszavak: sportmarketing, fogyasztói magatartás, szurkolói motiváció

JEL besorolás: $Z 2$

LCC: GV733-734.5

\section{Bevezetés}

A látvány-csapatsportágak az 1960-as években egyre inkább elterjedté váltak televíziónak köszönhetően, a szórakoztatóipar szerves részévé váltak (Muszbek 2012), következésképp a sportszakmai sikereken túl, a fogyasztók kiszolgálásról is szólniuk kell. A látványcsapatsportágak szereplőinek tehát kettős célrendszerrel kell müködniük, amelynek egy része sportszakmai, egy másik része pedig pénzügyi célokat jelent (András 2003) A pénzügyi céljaik 
kapcsán jelentős többségüknél elsősorban nem a profitmotívum jelenik meg, hanem a gazdasági stabilitás megteremtése, és a bevétel-kiadás közötti egészséges egyensúly fenntartása, amely hosszú távon biztosítja azt a feltételrendszert, amit felhasználva sportszakmai sikereket érhetnek el. András (2003) a hivatásos labdarúgásban öt piacot azonosított, amelyek a következők: fogyasztói-, szponzori-, közvetítési jogok-, merchandising- és játékospiac. Ez az öt piac a látvány-csapatsportágak mindegyikében fellelhető, kivételt ez alól csak a játékospiac képezhet, hiszen, a futballon kívül átigazolási összegek csak legritkább esetben fordulnak elő a sportolók szerződtetésekor. A piacok közül különösen fontos a fogyasztói piac, tekintettel arra, hogy az üzleti bevételek közvetlenül vagy közvetve a fogyasztóktól származnak (András 2003).

Kijelenthető tehát, hogy fogyasztók nélkül nem beszélhetünk hivatásos sportról.

A látvány-csapatsportágak, különös tekintettel a labdarúgásra, a rendszerváltás óta nézőszám problémákkal küszködnek, amelyet csak részben lehet a „rossz termék” érvvel magyarázni, olyan sportágakban pedig, mint például a kézilabda vagy a vízilabda nem is állja meg a helyét. Müller és munkatársai (2009, 2013) felhívják a figyelmet arra, hogy a passzív sportfogyasztáshoz mindig, valamilyen élmény kapcsolódik. Kassay (2018) szerint a látványcsapatsport mérkőzéseken ez az élménynyújtás marad el. A nézők kiszolgálása nemcsak a pályán, azon kívül is hiányos. Fontos, azonban megemlíteni, hogy a hosszú ideig elmaradt beruházások és fejlesztések (Bács - Kozma 2018) következtében a sportlétesítmények állapota, illetve minősége nem tette lehetővé a fogyasztók elvárásainak megfelelő kiszolgálást. A sportszolgáltatás színvonala, amelyre szignifikáns hatással van maga a létesítmény, befolyásolja a fogyasztói keresletet (Wakefield - Blodgett 1996, Shank 2001). Éppen ezért van nagy jelentősége annak, hogy az elmúlt években mind a hivatásos, mind az amatőr sportot kiszolgáló sportinfrastruktúra megújult Magyarországon (Ráthonyi-Odor - Borbély 2017, Stocker - Szabó 2017). Az új vagy felújított létesítmények átadása után, logikus, ésszerü volt az az elvárás, hogy rövidesen emelkedni fognak a nézőszámok a látvány-csapatsportágak mérkőzésein. Ez a növekedés ugyanakkor nem következett be, így a jegy és bérlet bevételek továbbra is csekély mértékben járulnak hozzá a klubok költségvetéséhez (Nagy - Bácsné 2014).

\section{Szurkolói motivációs skálák}

Nyugat-Európában és az Egyesült Államokban a passzív sportfogyasztás az egyik legkedveltebb szabadidős program, ezért az 1990-es években a sportgazdasági kutatások egyik fókuszává a fogyasztók viselkedése vált. A kutatókat elkezdte érdekelni, hogy egy-egy sportesemény iránti érdeklődést milyen tényezők befolyásolják (Baade - Tiehen 1990, Zhang et al. 1995, Kahle et al. 1996). Ezt követően a különböző befolyásoló faktorok közül (látványosság, gazdasági-, szocio-demográfiai tényezők stb) a szurkolói motivációk vizsgálata is népszerü kutatási téma lett (Wann 1995, Milne - McDonald 1999, Trail - James 2001, Funk et al 2009), azonban Magyarországon akár a marketing, akár a sporttudomány részéröl, mindezidáig elhanyagolt terület volt.

Az első szurkolói motivációs skálák (Wann 1995, Milne - McDonald 1999) egy későbbi vizsgálat során, nem állták ki a megbízhatóság és érvényesség próbáját. Az első, ami megfelelt e feltételeknek az az MSSC (Motivation Scale for Sport Consumption) skála, mely Trail és James (2001) nevéhez füződik. A szerzők 9 faktort (siker, ismeret, esztétika, dráma, szórakozás, család, vonzalom, teljesítmény és közösséghez való tartozás) azonosítottak, amelyekhez 3-3 item tartozik.

\section{Anyag és módszer}


Vizsgálatunk egy pilot kutatás egyetemi hallgatók körében, melynek célja az MSSC szurkolói motivációs skála adaptációja. Az MSSC skála egyik faktorát kihagytuk az adaptációból, tekintettel arra, hogy annak megbízhatósága és érvényessége megkérdőjelezhető. A szociodemográfiai kérdések mellett a megkérdezetteknek, így 24 állításra, 1-7 terjedő likert skálán kellett válaszolniuk annak megfelelően, hogy mennyire értenek egyet az adott állítással $(1=$ egyáltalán nem értek egyet, $7=$ teljes mértékben egyetértek). Kiemelnénk, hogy a kérdőív nem sportágspecifikus állításokat tartalmazott, így összehasonlíthatóvá válhatnak az egyes látványcsapatsportágak kedvelőinek tábora. Az MSSC adaptálása kényelmi mintavétellel történt. A fordítást követően a Debreceni Egyetem Gazdaságtudományi, illetve a Gyermeknevelési és Gyógypedagógiai Kar hallgatói körében végeztünk kérdőíves felmérést, melynek elemszáma 178 fö. A minta 57\%-a nö, 43\%-a férfi, 62\%-a a Gazdaságtudományi Karon tanul, 38\%-a pedig a Gyermeknevelési és Gyógypedagógiai Kar hallgatója. Családi állapotukat tekintve 47\%-uk egyedülálló, 51\%-uk párkapcsolatban, 2\%-uk pedig házas. A válaszadók 19 és 34 év közöttiek voltak a kérdőív kitöltésekor, közel 85\%-uk a 19-22 éves korosztályba tartozott (1. táblázat).

\begin{tabular}{lcrr}
\multicolumn{1}{c}{ Változó } & Kategória & Gyakoriság (db) & Arány \\
Nem & Férfi & 77 & $43 \%$ \\
Életkor & Nő & 101 & $57 \%$ \\
& $19-22$ & 150 & $84 \%$ \\
& $23-26$ & 19 & $11 \%$ \\
\multirow{2}{*}{ Családi állapot } & $27-30$ & 5 & $3 \%$ \\
& $31-34$ & 4 & $2 \%$ \\
\multirow{2}{*}{ Kar } & Egyedülálló & 83 & $47 \%$ \\
& Párkapcsolatban él & 90 & $51 \%$ \\
& Házas & 3 & $2 \%$ \\
& GTK & 110 & $62 \%$ \\
& GYGYK & 68 & $38 \%$
\end{tabular}

Forrás: saját kutatás, saját szerkesztés

Az adatokat az IBM SPSS Statistics 23 programmal dolgoztuk fel. Első lépésként a skálák megbízhatósági vizsgálatára Cronbach-alfa mutatót határoztunk meg. A Cronbach-alfa a legelterjedtebb a skálák reliabilitásának mérésére (Peterson - Kim, 2013). Az alfa az egyszerü tesztfelezés helyett, az összes lehetséges tesztfelezés korrelációs együtthatójának számtani átlaga (Kovács et al 2017), így egyfajta belsőkonzisztencia-mutatóként fogható fel (Takács Kárász 2014). A struktúra feltárására faktorelemzést végeztünk maximum likelihood módszerrel, amely előtt KMO-Bartlett tesztre került sor. A faktor struktúrát rotált faktormátrix segítségével mutatjuk be.

Tekintettel mintavételi eljárásra, valamint arra, hogy a kutatás csak egyetemisták körében zajlott, így természetesen nem tekinthető reprezentatívnak. A válaszadók valamennyien az Ygenerációhoz tartoznak, ez pedig azért fontos, mert például a labdarúgó-mérkőzéseken legkevésbé ők képviseltetik magukat. A helyszíni szurkolók kétharmada a 40 évnél idősebb korosztályba tartozik (Kassay 2018), így a fiatalok motivációjának és véleményének megismerése kardinális kérdés nemcsak a jövő, hanem a jelen szempontjából is.

\section{Eredmények}

Az eredmények alapján megállapítható, hogy a válaszadók között a legnépszerübb csapatsport tetemes előnnyel a labdarúgás. A kitöltők közel fele a futballt jelölte meg kedvenc sportágaként. 
A labdarúgást a kézilabda követi, némileg meglepő módon harmadik a röplabda, majd kosárlabda, vízilabda és jégkorong a sorrend (1. ábra). A röplabda „elökelő” helyezése feltételezhető módon annak köszönhető, hogy a mintában fiatal nők felülreprezentáltak.

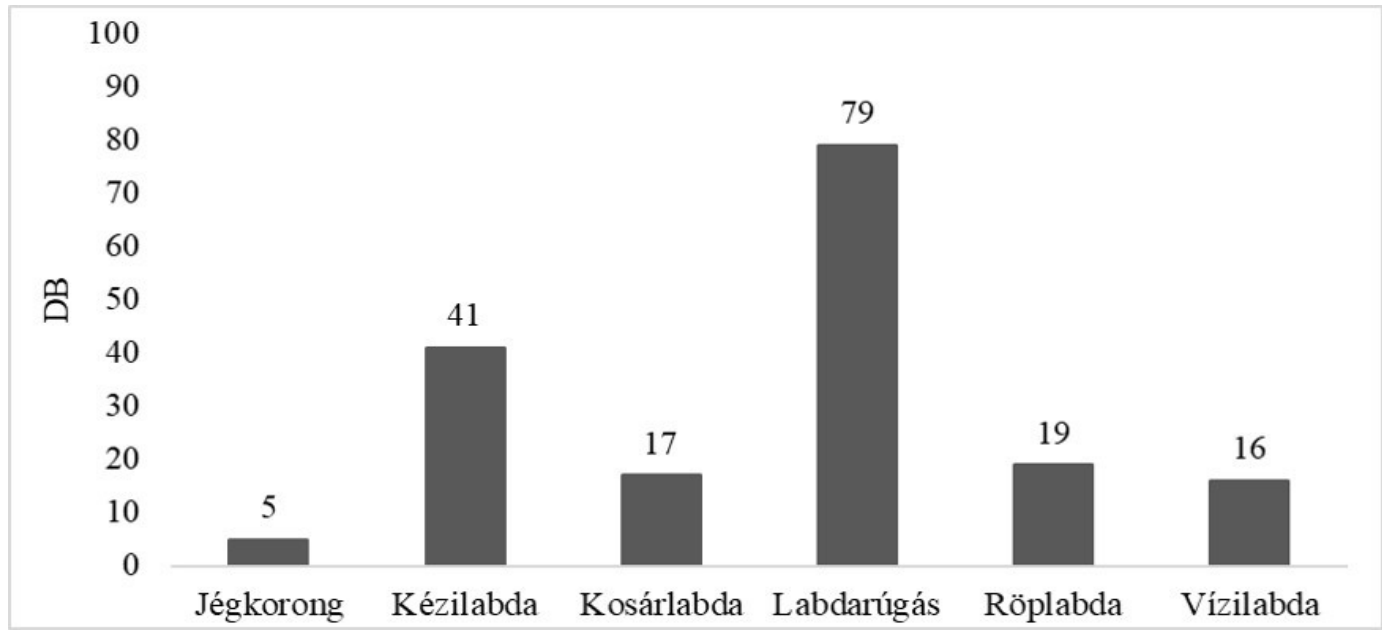

\section{1. ábra Kedvenc látvány-csapatsportág $(\mathrm{n}=178)$}

Forrás: Saját kutatás, saját szerkesztés

A Cronbach-alfa értékét 0,7 felett rendszerint megbízhatónak tekinthetjük (Kovács et al 2017). Mint már korábban említettük a 9 faktor közül egytől eltekintettünk, ugyanis az alfa értéke már a skála kialakításakor is 0,68 volt, ami megkérdőjelezhető. A reliabilitás vizsgálat eredményeként megállapítható, hogy az egyes faktorok Cronbach-alfa értékei az elfogadható 0,7 felettiek, a drámától eltekintve meghaladják a 0,8-at, amelyek már a jó kategóriába tartoznak. A kapott eredmények azt mutatják, hogy a skála megbízható, így alkalmas a faktorelemzés lefolytatására (2. táblázat).

\section{2. táblázat Reliabilitási vizsgálat}

Siker

Faktor

Ismeret

Esztétika

Dráma

Szórakozás

Vonzalom

Teljesítmény

Közösséghez való tartozás
Cronbach-alfa érték

0,88

0,89

0,85

0,77

0,89

0,85

0,87

0,82

Forrás: Saját kutatás, saját szerkesztés

A KMO-érték az egyik legfontosabb mérőszám annak a megítélésére, hogy a változók mennyire alkalmasak a faktorelemzésre. A KMO mutatószámot 0,7 felett megfelelőnek tekinthetjük (Sajtos - Mitev 2007). Jelen vizsgálatban a KMO-érték meghaladta a 0,7-es értéket, egészen pontosan 0,872, ami a nagyon jó kategóriába tartozik, és a Bartlett teszt is szignifikáns, azaz a változók összefüggenek. A KMO-érték és a szignifikáns Bartlett teszt azt mutatja, hogy a változók alkalmasak a faktorelemzésre (3. táblázat)

\section{3. táblázat KMO és Bartlett teszt}

KMO (Kaiser-Meyer-Olkin) 
Bartlett Teszt

Becsült khi négyzet

2829,715

Szabadságfok

276

Szignifikancia

, 000

Forrás: Saját kutatás, saját szerkesztés

A KMO és Barlett teszt után Varimax rotációt alkalmaztunk, melynek lefuttatása 5 faktort eredményezett, amelyek a variancia 62,84\%-át magyarázzák. A faktorelemzés nem tükrözi a Trail és James (2001) által feltárt 8 (a családdal együtt 9) faktort, ugyanis az itemek 5 faktorba rendeződnek. A rotált faktormátrixról azt olvashatjuk, hogy az esztétika, a dráma és a teljesítmény tényezőkhöz tartozó állítások egy faktorba kerültek, ahogyan a sikerhez és az ismerethez tartozó itemek is. A szórakozás, a vonzalom és a közösséghez való tartozás tényezők kapcsán hasonló eredmény mutatkozik, mint Trail és James (2001) vizsgálata során (4. táblázat).

\section{4. táblázat Rotált faktormátrix}

\begin{tabular}{|l|r|c|c|c|c|}
\hline & \multicolumn{5}{|c|}{ Faktor } \\
\cline { 2 - 6 } & 1 & 2 & 3 & 4 & 5 \\
\hline Teljesítmény 2 &, 801 & & & & \\
\hline Teljesítmény 1 &, 789 & & & & \\
\hline Teljesítmény 3 &, 741 & & & & \\
\hline Dráma 1 &, 656 & & & & \\
\hline Esztétika 2 &, 632 & & & & \\
\hline Esztétika 1 &, 622 & & & & \\
\hline Esztétika 3 &, 571 & & & & \\
\hline Dráma 2 &, 550 & & & & \\
\hline Dráma 3 &, 487 & & & & \\
\hline Siker 1 & &, 763 & & & \\
\hline Ismeret 1 & &, 759 & & & \\
\hline Siker 2 & &, 733 & & & \\
\hline Ismeret 2 & &, 698 & & & \\
\hline Ismeret 3 & &, 695 & & & \\
\hline Siker 3 & &, 650 & & & \\
\hline Vonzalom 2 & & &, 874 & & \\
\hline Vonzalom 3 & & &, 769 & & \\
\hline Vonzalom 1 & & &, 745 & & \\
\hline Szórakozás 1 & & & &, 800 & \\
\hline Szórakozás 2 & & & &, 761 & \\
\hline Szórakozás 3 & & & &, 605 & \\
\hline Közösség 2 & & & & &, 822 \\
\hline Közösség 3 & & & & &, 782 \\
\hline Közösség 1 & & & & &, 562 \\
\hline
\end{tabular}

Forrás: Saját kutatás, saját szerkesztés

Tekintettel a faktorelemzés eredményére 3, illetve 2 faktor esetében új megnevezésre van szükség. Az esztétika, a dráma, illetve a teljesítmény faktorokat összefoglalóan úgy gondoljuk, hogy a látványosság írja le legjobban. A siker tényezőhöz pedig olyan állítások tartoztak, mint például „személyes sikeremnek érzem, ha a csapat jól teljesít”, így véleményünk szerint a csapattal kapcsolatos ismeretekkel együtt e faktor elnevezésekor, a csapattal való azonosulás a 
legadekvátabb. Az MSSC szurkolói motivációs skála az adaptáció után, így 5 faktorból: a látványosságból, a csapattal való azonosulásból, a szórakozásból, a vonzalomból, illetve a közösséghez való tartozásból áll (5. táblázat).

\begin{tabular}{|c|c|c|c|}
\hline \multicolumn{4}{|c|}{ 5. táblázat MSSC szurkolói motivációs skála } \\
\hline \multicolumn{2}{|c|}{ Trail és James (2001) } & \multicolumn{2}{|c|}{ Balogh és Bácsné (2018) } \\
\hline Faktorok & Itemek száma & Faktorok & $\begin{array}{c}\text { Itemek } \\
\text { száma }\end{array}$ \\
\hline esztétika & 3 & & \\
\hline dráma & 3 & látványosság & 9 \\
\hline teljesítmény & 3 & & \\
\hline siker & 3 & & \\
\hline ismeret & 3 & csapattal való azonosulás & 6 \\
\hline szórakozás & 3 & szórakozás & 3 \\
\hline vonzalom & 3 & vonzalom & 3 \\
\hline közösséghez való tartozás & 3 & közösséghez való tartozás & 3 \\
\hline család & 3 & - & - \\
\hline
\end{tabular}

Forrás: Saját kutatás, saját szerkesztés

\section{Következtetések}

A magyar látvány-csapatsportágak valamennyi szereplője, kisebb-nagyobb mértékben nézőszám problémákkal kénytelen szembenézni. Annak érdekében, hogy a látványcsapatsportágak Magyarországon is az üzleti alapú müködés irányába mozduljanak, elengedhetetlen, hogy növekedjen a nézőszám, és vele együtt a jegy és bérletbevételek, hiszen ez a további piacokra is hatást gyakorolna. Természetszerüleg a több néző és szurkoló, befolyással lehet a merchandising bevételekre. A megtelt lelátókkal rendezett mérkőzések hozzájárulhatnak a közvetítési jogok értékének a növekedéséhez, a magasabb helyszíni átlagnézőszám, illetve a televíziós nézettség pedig a vállalatok érdeklődését is felkeltheti, amely szponzori bevételek formájában megjelenhet a klubok költségvetésében.

Az MSSC vagy a Kajos és munkatársai (2017) által adaptált SPEED-H skálák a passzív sportfogyasztók viselkedése mögött húzódó motivációk feltárására és megismerésére alkalmasak. A szurkolói motivációs skálák segíthetnek a látvány-csapatsportágak képviselőinek megérteni a szurkolók magatartását és viszonyulását a klubhoz. Az egyes helyi specialitások miatt feltételezhetően eltérések mutatkozhatnak az egyes befolyásoló tényezőkben, amelyet a szereplőknek rendkívül hasznos ismerniük, hiszen ezek előmozdíthatják a nézőszám emelkedést. Úgy gondoljuk, hogy a jövőben célszerü lenne egy reprezentatív mintán felmérést készíteni, és az egyes demográfiai jellemzőkkel összevetni, amelynek köszönhetően szegmentációs eszközként is szolgálhatna az MSSC.

A passzív sportfogyasztás visszaeséséhez számos társadalmi és kulturális tényező járult hozzá, amelyek motivációk mérésével nem, vagy csak részben mérhető fel. Azt is fontos megjegyezni, hogy valamennyi skála az Egyesült Államokban vagy a fejlett nyugat-európai sportközegben készültek. A szakirodalmak jelentős részében a nézőket nem szurkolóként, hanem fogyasztóként azonosítják. A fejlettebb, nyugati sportkultúrákban tulajdonképpen evidenciaként tekintenek arra, hogy az emberek életéhez hozzátartozik a sportesemények látogatása. Magyarországon azonban jelenleg azt a kérdést kell feltennünk, hogy miért nem járnak mérkőzésekre a lakosok, amelyet véleményünk szerint másféle megközelítéssel kell 
vizsgálni. Éppen ezért úgy gondoljuk, hogy a szurkolói motivációs skálák nagymértékben segíthetik a sportesemények nézőszám növekedését, mindazonáltal látni kell azok korlátait is.

\section{Köszönetnyilvánítás}

A publikáció elkészítését az EFOP-3.6.2-16-2017-00003 számú projekt támogatta. A projekt az Európai Unió támogatásával, az Európai Szociális Alap társfinanszírozásával valósult meg.

\section{Irodalomjegyzék}

1. András K. (2003): Üzleti elemek a sportban, a labdarúgás példáján keresztül. PhD. értekezés, Budapesti Közgazdaságtudományi és Államigazgatási Egyetem. 42-69.p.

2. Baade R. A. - Tiehen L. J. (1990): An analysis of Major League Baseball attendance, 1969-1987. In: Journal of Sport and Social Issues. Vol. 14, No. 1. 14-32.p. ISSN: 01937235 https://doi.org/10.1177/019372359001400102

3. Bács Z. - Kozma G. (2018): Sportlétesítmények a köz szolgálatában: a multifunkcionális stadionok. In: Magyar Sporttudományi Szemle, Vol. 15, No. 2. 27 34.p. ISSN: $1586-5428$

4. Funk, D. C. - Filo, K. - Beaton A. A. - Pritchard M. (2009): Measuring the motives of sport event attendance: Bridging the academic-practitioner divide to understanding behavior. In: Sport Marketing Quarterly, Vol. 18, No. 3.126-138.p. ISSN: 1061-6934

5. https://doi.org/10.1177/019372395019004004

6. Kahle L. R. - Kambara K. M. - Rose G. M. (1996): A functional model of fan attendance motivations for college football. In: Sport Marketing Quarterly, Vol. 5, No, 4. 51-60.p. ISSN: 1061-6934

7. Kajos A. - Prisztóka Gy. - Paic R. (2017): A nézőtéri sportfogyasztás motivációit mérő, magyar nyelvű „SPEED-H” skála validációja és néhány eredménye. In: Vezetéstudomány Vol. 48, No.10. 19-31.p. ISSN: 0133-0179 https://doi.org/10.14267/VEZTUD.2017.10.03

8. Kassay L. (2018): Ismerjük a helyszíni szurkolás nézői attitüdjeit a hazai hivatásos labdarúgásban? In: Magyar Sporttudományi Szemle, Vol. 15, No. 1. 4-12.p. ISSN: $1586-5428$

9. Kovács B. - Szakály Z. - Kontor E. - Polereczki Zs. (2017): A piacorientáció kulturális és magatartási megközelítésének empirikus összehasonlító elemzése. In: Jelenkori Társadalmi és Gazdasági Folyamatok, Vol. 12, No. 4. 159-174.p. ISSN: 1788-7593

10. Milne G. R. - McDonald M. A. (1999): Sport marketing: Managing the exchange process. Jones and Bartlett Publishers, Sudbury. ISBN: 9780763708733

11. Müller A. - Bíró M. - Hidvégi P. - Váczi P. - Plachy J. - Juhász I. - Hajdú P. - Seres J. (2013): Fitnesz trendek a rekreációban. In: Acta Academiae Agriensis. XL. 25-35.p. ISSN 1498-6917

12. Müller A. (2009): A legújabb trendek a sportmarketing és menedzsment területén. In: Magyar Sporttudományi Társaság Sportinnovációs Szakbizottság Évkönyve. 59-63.p.

13. Muszbek M. (2012): Sport és gazdaság. In: Sterbenz T., Géczi G. (szerk.): Sportmenedzsment. Semmelweis Egyetem Testnevelési és Sporttudományi Kar, Budapest. 253-255.p. ISBN: 9786155196010.

14. Nagy I. Z., Bácsné B. É. (2014): Szervezeti átalakulások futballvállalkozásoknál. In: ACTA Agraria Debreceniensis, 2014, No. 58.141-146p. ISSN: 1587-1282

15. Peterson R. A. - Kim Y. (2013): On the relationship between coefficient alpha and composite reliability. In: Journal of Applied Psychology. Vol. 98, No. 1. 194-198.p. ISSN: 0021-9010 http://dx.doi.org/10.1037/a0030767 
16. Ráthonyi-Ódor K. - Borbély A. (2017): Sport - Finanszírozás - eredményesség. In: Testnevelés, Sport, Tudomány / Physical Education, Sport, Science. Vol. 2, No. 1-2. 67-73.p. ISSN: 2498-7646

17. Sajtos L. - Mitev A. (2007): SPSS Kutatási és adatelemzési kézikönyv. Alinea Kiadó, Budapest. ISBN: 9789639659087

18. Shank M. D. (2001): Sport Marketing - A Strategic Perspective. Prentice Hall, New Jersey. ISBN: 9780130407917

19. Stocker M. - Szabó T. (2017): A sportirányítás gazdasági kérdései. Magyar Sporttudományi Társaság, Budapest. 56-78.p. ISBN: 9786155187124.

20. Takács Sz. - Kárász J. (2014): Egy egyszerü, újfajta kereszt-validálási eljárás bemutatása. In: Phychologia Hungarica Caroliensis. Vol. 2, No. 1. pp. 65-77.p. ISSN: 2064-2504

21. Trail G. - James J. (2001): The motivation scale for sport consumption: assessment of the scale's psychometric properties. In: Journal of Sport Behavior. Vol. 24, No. 1. 108127.p. ISSN:0162-7341

22. Wakefield K. L. - Blodgett J. G. (1996): The effect of the servicescape on the customers' behavioral intentions in leisure service settings. In: Journal of Services Marketing. Vol. 10, No. 4. 45-61.p. ISSN: 0887-6045 https://doi.org/10.1108/08876049610148594

23. Wann D. (1995): Preliminary validation of the sport fan motivation. In: Journal of Sport and Social Issues, Vol. 19, No. 5. 377-396.p. ISSN: 0193-7235

24. Zhang J.J. - Pease D.G. - Hui S.C. - Michaud T.J. (1995). Variables affecting the spectator decision to attend NBA games. In: Sports Marketing Quarterly, Vol. 4, No. 4. 29-39.p. ISSN: 1061-6934. 